\title{
Sağ Pulmoner Artere Erken Dönem Embolize Olmuş Atrial Septal Defekt Kapama Cihazının Tedavisi: İkinci Bir Girişim mi, Açık Cerrahi mi?
}

Menagement of an Early Embolised Atrial Septal Defect Occluder Device at The Right Pulmonary

Artery: Should It be Second Intervention or Open Surgery?

Mustafa ALDEMIR', Gülay ÖZKEÇECi', Fahri ADALI ${ }^{1}$

'Kocatepe University Department of Cardiovasculer Surgery, Afyonkarahisar

${ }^{2}$ Kocatepe University Department of Cardiology, Afyonkarahisar

\section{öz}

Atrial septal defektlerin perkütan transkateter yöntem ile kapatılması, sternotomi ve kardiyopulmoner by-pass gerektirmemesi nedeni ile uygun vakalarda sıklıkla tercih edilir olmuştur. Ancak, defekt kapama cihazının kalp boşluklarından birine yada vasküler dolaşıma migrasyonu en korkulan komplikasyon olarak karşımıza çıkabilmektedir. Sunulan yazıda, perkütan yöntemle başarılı bir şekilde kapatıldıktan 24 saat sonra sağ pulmoner artere embolize olmuş bir ASD kapama cihazının cerrahi olarak çıkarılması sunulmuştur.

Anahtar Kelimeler: ASD, transkateter cihaz, embolizasyon

\section{ABSTRACT}

Percutaneous transcatheter occlusion of atrial septal defects avoiding sternotomy and cardiopulmonary bypass has become increasingly accepted alternative practice to open surgical closure. But, migration of the device to any cardiac chamber or into the circulation is the most dreaded complication. In this present case, we reported a surgical management of an embolized ASO device at the right pulmonary artery on the next day of succesfull percutaneous ASD closure.

Keywords: ASD, transcatheter device, embolization 


\section{INTRODUCTION}

Transcatheter occlusion devices have been increasingly used to close some convenient atrial septal defects (ASD). This technique have some advantages comparing to open surgery such as lacking of any incision, improving recovery and avoiding cardiopulmonary bypass. On the other hand, it may cause some challenging complications such as, incomplete closure due to malposition or dislocation of the device, femoral or iliac artery injury as a preliminary puncture site complication, arrythmias and perforation of any cardiac chamber, oftenly left ventricle (1). Incidense of ASO (Atrial Septal Occluder) device dislocation has been reported approximataly less than 1\% (2). In the previous literature, landing space of ASO after dislocation has been reported most commonly to the right pulmonary artery as in our case or to the right atrium (3). In this case, we aimed to discuss the menagement strategies of dislocation problems.

\section{CASE REPORT}

A 35-year old-male patient having palpitation and dyspnea on exercise for the last one year, underwent an uneventfull device closure with The GOREVR Septal Occluder (GSO, W.L GORE \& Associates, Flagstaff, AZ) under transesophageal echocardiographic (TEE) guidance. He was fine at first postoperative day follow-up. During, routine postinterventional echocardiographic study, it was seen that the device wasn't in place. Fluoroscopy was done immediately, and the device was found out at the orifice of the right pulmonary artery. The place of the device was confirmed by CT scan of thorax. (figure I). The device was oriented longitudinally being it's snaerable part at the distal site not permitting percutaneous removal. Open surgery was decided to remove the device and to close the ASD.

The patient was transferred to the operating room immediately. Under general anaestesia, Standard median sternotomy was done. Through aorta-bicaval cannulation cardiopulmonary by-pass was initiated. After dissection of the main pulmonary artery from assending aorta, cross clamp was applied and diastolic cardiac arrest was established via antegade crystalloid cardioplegia. Between two pledgeted polypropilene sutures placed on the main pulmonary artery $3-4 \mathrm{~cm}$ above the right ventriculer outflow tract, a longitudinal incision was made. The device at the orifice of right pulmonary artery was seen and removed easily by grasping with a long pencet (figure II). After suturing main pulmonary artery incision, through right atrial approach, by using $4 / 0$ plypropilene suture, ASD was closed primarily (figure 3). The postoperative period of the patient was uneventfull, he was discharged on the 4th P.O. day.

\section{DICUSSION}

Open heart surgery was the unique option to close atrial septal defects before 1976 in which King and Mills reported the feasibility of percutaneous closure of ASD (4). Interventional ASD closure has been now increasinglyaccepted method, because of cosmetic benefits, reduced morbidity, short learning curve and reduced hospital stays. But, there is no any intervention being free of complication. Tamponade caused by cardiac perforation, cerebral emboli, device dislocation or migration, residual shunt, vasculer injury at preliminary site and induced mitral regurgitation can be mentioned as important patterns of it's complications (1). There is even a report in the literature referring device dislocation due to paroxysmal coughing early after percutaneous closure of atrial septal defect (5). Al-Anani SJ at al. Reported two ASO cases leading atrioventricular (AV) block resistant to medical therapy within $48 \mathrm{hr}$ after uncomplicated intervention. They were obliged to send their patients to surgery for removal of devices (6).

Among the complications of ASO closure, the device embolization is a potential life threatening complication requiring immediate removal (7). Ueda $\mathrm{H}$. at al. reported embolization of ASO devices as $0.48 \%$, but it would be higher in less experienced hands (8). ASO device embolization are commonly due to undersized 
ASO, small left atrium to accommodate the device, inadequate or floppy rim and opera $\neg$ tor-related technical issues (9). Device embolization is most commonly seen during the first day after intervention. Small aortic rim is mostly responsable fort that. Acute changes in intracardiac pressure is another potential cause of device embolization (10).

In this present case, embolization was thought to be due to thin and floppy membra nous nature of posterior portion of the atrial septum as we confirmed during operation. Our patient was asymptomatic, because, pulmonary flow was furtunately, not obstructed due to longitudinal orientation of the device. Percutaneous removal of the device was not adequate because of the orientation of it precluding snaring. We eventually decided to remove surgically.

As an alternative to open cardiac surgery, minimally invasive surgical issues with or without robotic Da Vinci surgical systems must be considered before facing to transcatheter interventions. Minimally invasive thoracoscopic closure of ASD is some similar to transcatheter interventions in respect to being less invasive, causing less pain, avoiding trauma from midline sternotomy, not using the steel wires, and leading less bleeding after operation (11). Kim JE. at al. reported a retrospective study including 50 patients undergoing ASD closure with minimal invasive technique without any complication (12).

In conclusion, first of all, criteria for indication of ASO intervention must be attentively carried out. Close folow-up with echocardiography for cilent complications is mandatory even in asymptomatic patients. Selection of the method to remove embolized device if percutaneous or surgery is depend on device orientation and center related factors. Surgery seems to be a reasonable preference for the longitudinally oriented devices and in less experienced interventional centers.

\section{REFERENCES}

1- Berdat PA, Chatterjee T, Pfammatter JP, et al. Surgical management of complications after transcatheter closure of an atrial septal defect or patent foramen ovale. J Thorac Cardiovasc Surgery 2000:120(6):1034-9.

2- Amin Z, Hijazi ZM, Bass JL, et al.. Erosion of Amplatzer septal occluder device after closure of secundum atrial septal defects: review of registry of complications and recommendations to minimize future risk. Catheter Cardiovasc Interv 2004;63(4):496-502.

3- Hu C, Huang S, Xu Z, Huang J. Hybrid treatment of a dislocated atrial septal occluder device at the bifurcation of the left and right common iliac artery. Interact Cardiovasc Thorac Surg 2013;16(5):701-2.

4- Raghuram AR, Krishnan $R$, Kumar $S$, Balamurugan K. Complications in atrial septal defect device closure. Interact Cardiovasc Thorac Surg 2008;7(1):167-9.

5- Bartel T, Bonatti JO, Müller S. Device dislocation, probably due to paroxysmal coughing early after percutaneous closure of secundum type atrial septal defect. Am J Cardiol 2008;101(4):548-9.

6- Al-Anani SJ, Weber $\mathrm{H}$, Hijazi ZM. Atrioventricular block after transcatheter ASD closure using the Amplatzer septal occluder: risk factors and recommendations. Catheter Cardiovasc Interv 2010;75(5):767-72.

7- Son JW, Park JS. Subacute, silent embolization of amplatzer atrial septal defect closure device to the pulmonary artery. J Cardiovasc Ultrasound 2012;20(4):201-4.

8- Ueda H, Yanagi S, Nakamura H, et al. Device closure of atrial septal defect: immediate and mid-term results. Circ J 2012;76(5):1229-34.

9- Levi DS, Moore JW. Embolization and retrieval of the Amplatzer septal occluder. Catheter Cardiovasc Interv 2004;61(4):543-7.

10- Mashman WE, King SB, Jacobs WC, Ballard WL. Two cases of late embolization of Amplatzer septal occluder devices to the pulmonary artery following closure of secundum atrial septal defects. Catheter Cardiovasc Interv 2005;65(4):588-92.

11- Liu G, Qiao Y, Ma L, Ni L, Zeng S, Li Q. Totally thoracoscopic surgery for the treatment of atrial septal defect without of the robotic Da Vinci surgical system. J Cardiothorac Surg. 2013 May 1;8(1):119. [Epub ahead of print.

12- Kim JE, Jung SH, Kim GS, Kim JB, Choo SJ, Chung CH, Lee JW.Surgical Outcomes of Congenital Atrial Septal Defect Using da VinciTMSurgical Robot System. Korean J Thorac Cardiovasc Surg. 2013 Apr;46(2):93-7. doi: 10.5090/kjtcs.2013.46.2.93. Epub 2013 Apr 9 